\title{
Coxsackievirus and Adenovirus Receptor
}

National Cancer Institute

\section{Source}

National Cancer Institute. Coxsackievirus and Adenovirus Receptor. NCI Thesaurus. Code C104701.

Coxsackievirus and adenovirus receptor ( $365 \mathrm{aa}, \sim 40 \mathrm{kDa}$ ) is encoded by the human CXADR gene. This protein is involved in both the formation of the epithelial apical junction complex and viral infection. 